\title{
EFFECT OF LEADERSHIP, MOTIVATION AND CULTURAL ORGANIZATION TO THE PERFORMANCE OF EMPLOYEES IN KPP PRATAMA WATAMPONE
}

\author{
Muhammad Umar Data (STIEM Bongaya) \\ Muhammad Tafsir (STIEM Bongaya)
}

\begin{abstract}
This study aims to determine the effect of leadership, motivation, and Cultural Organization on the performance of Employees in the Tax Office Primary Watampone. The sample used in this study were 50 people with saturated sample method. This research method using multiple linear regression analysis. Based on the results of data analysis and hypothesis testing showed that the results of this study indicate that the variable $\mathrm{F}$ test consisting of Leadership, Motivation and Cultural Organization simultaneously significant positive effect on the performance of employees in the Tax Office Primary Watampone.T significant test results (t test) for Leadership and motivation variable partially shows a significant positive effect on employee performance and Cultural Organization adversely affect the performance of employees in the Tax Office Primary Watampone. Results determinant coefficient (R2) has the meaning that leadership, motivation and organizational culture as an independent variable able to explain the performance of an employee as the dependent variable and has a very strong and positive relationship, while the rest is explained by other factors that are not included in this study.
\end{abstract}

Key words : Leadership, motivation, organitation culture and performance

\section{PRELIMINARY}

\section{A. Background}

Creating employee performance is not easy because the performance can be created when the variables that influence it, among others, work motivation, leadership and organizational culture / company can be accommodated well and accepted by all employees within an organization / company. Gibson (1996) in Ermayanti (2001: 3) and Brahmasari (2005: 96), argued that organizational performance depends on individual performance or in other words individual performance will contribute to organizational performance, meaning that the behavior of member organizations both individually and groups provide strength for organizational performance.

Employee performance is closely related to the results of one's work in the organization. The results of the work can involve quality, quantity and timing. While employee performance is influenced by education, motivation, environment, discipline, regulation and most importantly is influenced by leadership within the organization (Waridin, 2005). As a leader to achieve organizational goals is not an easy thing (Organizational leaders can perform various ways in affecting other people or subordinates.

Robin and Judge (2008), define motivation as a process that explains the intensity, direction and persistence of individuals to achieve goals. The problem of motivation in the organization should be taken as a serious concern in human resource management. Modern organizations today must make members as assets, not just as a means of production alone. For that the organization needs to create a conducive condition that can make members feel comfortable, fulfilled their needs, so it is expected that their motivation is also maintained to jointly achieve the vision and mission of the organization.

Robbins (1996) argues that a strongly cultured organization will have certain characteristics that can provide an attraction for individuals to join, think, act and behave in accordance with the values of the organization. 
Along with the changing condition of the environment and the changing business world and the demands of the society, the Directorate General (DGT) of Taxation needs to improve the system, the working mechanism and the performance of tax institutions, this is reinforced by the many negative views of tax observers, the general public and Taxpayers against the poor performance of employees of the Directorate General of Taxes (intranet Ditjen Pajak, 2005). The success of the modernization undertaken by the Directorate General of Taxes will depend heavily on awareness, understanding, preparedness and ability of employees in adapting to change. Between the organization and employees is a unity that has a relationship that is simultaneous and must be balanced.

\section{B. Problem Formulation}

The formulation of the problems examined in this study is

1. Is simultaneously leadership, motivation and organizational culture affect the performance of employees in the Primary School KPP Watampone

2. Is the partial leadership, motivation and organizational culture affect the performance of employees in the Primary School KPP Watampone

\section{LITERATURE REVIEW}

\section{A. Theoretical Basis}

Human beings as social beings in this life are always associated in the bonds of various organizations, whether organizations are social, economic organizations, religious organizations and so forth until the organization is government where the organization is a form of partnership between two or more people who work together to achieve common goals Siagian: 1987)

A leader or manager of an institution is a person who works with the help of others, they do not run all the work or responsibility that is levied on him alone but asks others to run it or member and direct the tasks to subordinates

\section{Prior Research}

Suharto (2004) conducted a study on the performance of employees of Disperindag PropinsiJawa Tengah by using variable job satisfaction, motivation and organizational culture. The results showed that the partial variable of job satisfaction, motivation and organizational culture have a positive and significant impact on employee performance.Sedangkan simultaneously variable job satisfaction, motivation and organizational culture have a positive and significant impact on employee's performance. The policy priority that management of Disperindag of Central Java Province is viewed based on the largest coefficient value, the first priority is on employee job satisfaction variable, second priority is employee motivation variable, and the last is the organizational culture variable.

Thoyib (2005), states the existence of interrelationships between organizational culture, strategy, and performance. Suharto and Budi Cahyono (2005) examined the influence of organizational culture, leadership and work motivation on human resource performance in the secretariat of DPRD Province Central Java, the results of the study have a positive influence between the variables of organizational culture, leadership and work motivation on employee performance. 
Sugiman (2006) conducted a research title "the influence of leadership, work motivation and work discipline on the work performance of employees in the administration section of Purwarejo District Education Office". This research uses survey method, data collection tool used is questionnaire using census method with 38 respondents people. Multiple regression analysis is carried out to test the hypothesis in this study and carried out using a computer program for Windows. In the hypothesis that leadership, work motivation and work discipline simultaneously affect employee performance can be accepted.

\section{Organizational Culture}

Like the notions of leadership and motivation, the understanding of organizational culture is widely expressed by scientists who are experts in organizational culture, but there is still little understanding about the meaning of the concept of organizational culture or how organizational culture must be observed and measured (Brahmasari, 2004). Further Brahmasari ( 2004: 16) suggests that this is due to a lack of understanding of the theory formulation of organizational culture, its description, and its possible relation to the impact of performance. Ndraha (2003: 4) in Brahmasari (2004: 12) suggests that corporate culture (corporateculture) is an application of organizational culture (organizational culture) to a business entity or company. These two terms are often used for the same purpose in turn.

\section{Leadership}

Dubrin (2005: 3) argues that leadership is an attempt to influence many people through communication to achieve goals, ways to influence people with instructions or commands, actions that cause others to act or respond and cause positive change, important dynamic forces that motivate and coordinate the organization in order to achieve the goal, the ability to create confidence and support among subordinates for organizational objectives can be achieved. Siagian (2002: 62) suggests that leadership is the ability of a person to influence others (his subordinates) in such a way that others want to do the will of the leader even though he may not like it personally.

\section{Work Motivation}

Robbin (2002: 55) argues that motivation is a desire to do as a willingness to issue a high level of effort for organizational goals, which is conditioned by the ability of the effort to meet an individual's needs. Siagian (2002: 94) suggests that in organizational life, including life working in business organizations, aspects of absolute work motivation get serious attention from managers.

\section{Employee performance}

Every human being has the potential to act in various forms of activity. The ability to act can be obtained by humans either naturally (at birth) or studied. Hasibuan in Sujak (1990) and Sutiadi (2003: 6) suggests that performance is a result of work achieved by a person in carrying out tasks that are charged to him based on skills, experience and sincerity and time. In other words, performance is the result of work achieved by someone in carrying out the tasks assigned to him according to the criteria set. Furthermore As'ad in Agustina (2002) and Sutiadi (2003: 6) suggested that a person's performance is a measure of the extent to which a person's success in carrying out his job duties. There are 3 (three) main factors that affect the performance of the individual (ability to work), work effort (desire to work), and organizational support (opportunity to work).

\section{RESEARCH METHODS}

\section{A. Population and Sample}


The population in this study is the Primary Tax Service Officer Watampone with all the characteristics owned and amounted to 50 people. According to Arikunto (1998: 115) the population is the whole of the research subject. According to Sugiono (2006), if all members of the population are sampled called saturated sampling because of the limited number of population then all employees as many as 50 people become respondents

\section{B. Validation and Reliability Testing}

\section{Test Validity}

The validity level of this research instrument is known through validity test by using SPSS Windows release 19 program which is conducted on questionnaires with 24 items of question through sample validity of instrument test of 30 people. The rtable value for $N=30$ with $\mathrm{df}=25 \%$ confidence level that is equal to 0.361 .

Based on the results of the trial questionnaire to 30 respondents obtained the following results:

Table 1 Test of the Validity of Leadership Variables

\begin{tabular}{cccc}
\hline No & $\mathrm{R}_{\text {counts }}$ & $\mathrm{r}_{\text {table }}$ & Criteria \\
\hline 1 & 0,430 & 0,361 & Valid \\
2 & 0,459 & 0,361 & Valid \\
3 & 0,759 & 0,361 & Valid \\
4 & 0,699 & 0,361 & Valid \\
5 & 0,882 & 0,361 & Valid \\
6 & 0,629 & 0,361 & Valid \\
\hline
\end{tabular}

the entire instrument of each item statement is valid and can be used in research.

Table 2 Test Validity Variable Motivation

\begin{tabular}{llll}
\hline No & $\mathrm{R}_{\text {count }}$ & $\mathrm{r}_{\text {table }}$ & Criteria \\
\hline 1 & 0,476 & 0,361 & Valid \\
2 & 0,816 & 0,361 & Valid \\
3 & 0,526 & 0,361 & Valid \\
4 & 0,624 & 0,361 & Valid \\
5 & 0,728 & 0,361 & Valid \\
6 & 0,615 & 0,361 & Valid \\
\hline
\end{tabular}

Source: Analysis of research data 2015

The results of the analysis concluded that all instrument statements of each item were valid and could be used in research.

Table. 3 Validity Test of Organizational Culture Variables

\begin{tabular}{llll}
\hline No & $\mathrm{R}_{\text {count }}$ & $\mathrm{r}_{\text {table }}$ & Criteria \\
\hline 1 & 0,546 & 0,361 & Valid \\
2 & 0,796 & 0,361 & Valid \\
3 & 0,661 & 0,361 & Valid \\
4 & 0,394 & 0,361 & Valid \\
5 & 0,578 & 0,361 & Valid \\
6 & 0,649 & 0,361 & Valid \\
\hline
\end{tabular}

Source: Analysis of research data 2015 
So it can be concluded that all instrument statements of each item are valid and can be used in research.

Table .4 Test the Validity of Performance Variables

\begin{tabular}{llll}
\hline No & $\mathrm{R}_{\text {count }}$ & $\mathrm{R}_{\text {table }}$ & Criteria \\
\hline 1 & 0,667 & 0,361 & Valid \\
2 & 0,704 & 0,361 & Valid \\
3 & 0,789 & 0,361 & Valid \\
4 & 0,687 & 0,361 & Valid \\
5 & 0,545 & 0,361 & Valid \\
5 & 0,377 & 0,361 & Valid \\
\hline
\end{tabular}

Source: Analysis of research data 2015

The entire instrument of each item statement is valid and can be used in research.

2. Test Reliability Based on the reliability test results obtained as follows:

Table .5 Variable Reliability Test

\begin{tabular}{lllll}
\hline No & Variabel & $\begin{array}{l}\text { Value } \\
\text { Cronbach's Alpha }\end{array}$ & $\begin{array}{l}\text { Minimal } \\
\text { Cronbach's } \\
\text { Alpha }\end{array}$ & Result \\
\hline 1 & Leadership & 0,876 & 0,60 & Reliabel \\
2 & Motivation & 0,876 & 0,60 & Reliabel \\
3 & Org Culture & 0,876 & 0,60 & Reliabel \\
4 & Performance & 0,876 & 0,60 & Reliabel \\
\hline
\end{tabular}

Source: Analysis of research data 2015

Hypothesis testing

1. Multiple Linear Regression Analysis

Regression analysis is used to determine the strength of independent variables to dependent.

\section{a. Simultaneous Significance Test (F test)}

After the validity and reliability test, it is concluded that the model can be used, then the next step is to test hypothesis. To test the hypothesis about the influence of leadership, motivation and organizational culture on performance $F$ test by using multiple regression to determine the influence of independent variables simultaneously to dependent variable with level of significance alpha $5 \%$ or 0,05 with criterion: (1) If value of research sig $<0.05$, then $\mathrm{HO}$ is rejected and $\mathrm{H} 1$ accepted, (2) If sig value of research $>0,05$, then $\mathrm{HO}$ accepted and $\mathrm{H} 1$ is rejected. The result of hypothesis test with $\mathrm{F}$ test is presented in table 6 below:

Table .6 Simultaneous Significance Test (F Test)

\begin{tabular}{|ll|l|l|l|l|l|}
\hline Model & & $\begin{array}{l}\text { Sum of } \\
\text { Squares }\end{array}$ & df & $\begin{array}{l}\text { Mean } \\
\text { Square }\end{array}$ & F & Sig. \\
\hline \multirow{2}{*}{1} & Regression & 114.707 & 3 & 38.236 & 7.412 & $.000^{\mathrm{b}}$ \\
& Residual & 237.293 & 46 & 5.159 & & \\
& Total & 352.000 & 49 & & & \\
\hline
\end{tabular}

a. Dependent Variable: PERFORMANCE

b. Predictors: (Constant), LEADERSHIP, MOTIVATION, ORGANIZATIONAL CULTURE

Source: Processed Data of SPSS Data 2015 
From the $F$ test or Anova test obtained a significant level value of $=0,000$. Because of the smaller probability value $(<)$ of $\alpha=0.05$. Then $\mathrm{Ho}$ is rejected, and $\mathrm{H} 1$ is accepted. So leadership, motivation and organizational culture influence together or simultaneously on performance

\section{b Partial Significance Test (t test)}

After testing the hypothesis with the $F$ test, testing the hypothesis continued with the $t$ test which aims to determine the effect of independent variables partially on the dependent variable with an alpha significance level of $5 \%$ or 0.05 with the following criteria: (1) If $p$ value $<0.05$, then $\mathrm{HO}$ is rejected or $\mathrm{H} 1$ is accepted, (2) If the $\mathrm{p}$-value is $>0.05$, then $\mathrm{HO}$ is received and $\mathrm{H} 1$ is rejected. The result of hypothesis testing with t test is presented in table 7 below:

Table 7. Partial significance test (t test)

\begin{tabular}{|c|c|c|c|c|c|c|}
\hline \multicolumn{7}{|c|}{ Coefficientsa } \\
\hline \multirow[t]{3}{*}{ Model } & & \multicolumn{2}{|c|}{ Unstandardized } & Standardized & & \\
\hline & & \multicolumn{2}{|l|}{ Coefficients } & Coefficients & & \\
\hline & & B & Std. Error & Beta & $\mathrm{t}$ & Sig. \\
\hline 1 & (Constant) & 8.844 & 3.391 & & 2.608 & .012 \\
\hline & Leadership & .352 & .150 & .320 & 2.338 & .024 \\
\hline & Motivation & .324 & .138 & .393 & 2.357 & .023 \\
\hline & Org Culture & -.044 & .155 & -.048 & -.284 & .778 \\
\hline a. Variable & Dependent: & mance & & & & \\
\hline
\end{tabular}

Based on the results of the SPSS test above, the regression equation that describes the variables in this study are:

$$
Y=8,844+0,352 X 1+0,324 X 2-0,044 X 3+0,674 \varepsilon 1
$$

Based on the SPSS testing of individual parameters, the results of individual leadership testing showed that the unstandardized coefficients beta value was 0.352 and a significant value of $0.024<0.05$, so $\mathrm{H} 1$ was accepted. Thus taken the conclusion that the leadership variable has a positive and significant impact on performance.

Individual motivation test results showed that the unstandardized coefficients beta value was 0.324 and a significant value of $0.023<0.05$, so $\mathrm{H} 2$ was accepted. Thus taken the conclusion that the variable of motivation have positive and significant effect to performance. The results of individual organizational culture testing showed an unstandardized coefficients beta value of -0.044 and a significant value of $0.778>0.05$, so $\mathrm{H} 2$ was rejected. Thus the conclusion is that organizational culture variables do not have a partial effect on performance.

\begin{tabular}{|c|c|c|}
\hline & $\mathrm{T}$ & Sig \\
\hline Kepemimpinan & 2.608 & 0.012 \\
\hline Motivasi & 2.338 & 0.024 \\
\hline Budaya Organisasi & 2.357 & 0.023 \\
\hline Kinerja & -0.284 & 0.778 \\
\hline $\begin{array}{l}\mathrm{F} \\
\mathrm{R} \\
\mathrm{R} \text { Square }\end{array}$ & $\begin{array}{l}7.412 \\
.571 \square \\
0.326 \\
\end{array}$ & \\
\hline
\end{tabular}

Table 8.Recapitulation Data Processing 


\section{Source: Processed Data of SPSS Data 2015}

\section{c. Coefficient of Determination (R2)}

The coefficient of determination (R2) aims to find out how big the ability of leadership variable (X1), motivation (X2) and organizational culture (X3) as a whole in explaining performance variable $(Y)$. The results of the coefficient of determination analysis can be seen as follows:

Table 4.12 Coefficient of determination (R2)

Model Summary

\begin{tabular}{|l|l|l|l|l|}
\hline Model & $\mathrm{R}$ & R Square & $\begin{array}{l}\text { Adjusted } \\
\text { R Square }\end{array}$ & $\begin{array}{l}\text { Std. Error } \\
\text { of the } \\
\text { Estimate }\end{array}$ \\
\hline 1 & $.571^{\mathrm{a}}$ & .326 & .282 & 227.124 \\
\hline
\end{tabular}

a. Predictors: (Constant), Leadership, Motivation, Organiation Culture

Source: Processed Data of SPSS Data 2015

Results of SPSS model summary analysis showed that the magnitude of RSquare is 0.326 or $32.6 \%$. Performance variables can be explained by leadership $32.6 \%$ and the remaining $67.4 \%$ is explained by other variables outside the model.

Based on the R2 test in table 4.12 , the value $\varepsilon 1=1-\mathrm{R} 2=1-0.326=0.674$. The empirical causal effects between leadership variables (X1) of motivation variables (X2) and organizational culture variables $(\mathrm{X} 3)$ on Performance $(\mathrm{Y})$ can be illustrated by structural equations:

\section{F. DISCUSSION}

In this section will be discussed the discussion of the results of the study as follows:

This study has similarities with previous research made by Sugiman (2006) with the title "The Effect of Work Motivation Leadership, and Work Discipline Against Work Performance of Employees of the Purworejo District Education Office". In Sugiman's research, leadership, work motivation, and work discipline together and partially have a positive influence on 
employee performance and work discipline has the most dominant influence on employee performance.

The $\mathrm{R}$ value of 0.833 means relations between Leadership, Motivation, and Organizational Culture Against Employee Performance of Watampone Primary KPP means that there is a very strong relationship and the coefficient of determination (R2) or R - Square of 0.326 indicates that Leadership, Motivation, and Organizational Culture as an independent variable, able to explain the performance of KPP Pratama Watampone Employee as a dependent variable of $69.4 \%$ while the remaining $30.6 \%$ is explained by other factors.

Based on the Test SImultan (Test F) note that the value of Fhitung $=38.236$ significant value is 0.000 so that the decision taken is $\mathrm{H} 1$ accepted. This means that Leadership, Motivation, and Culture Organization together or simultaneously have a significant effect on the Performance of KPP Pratama Watampone Employee.

\section{The Influence of Leadership on Performance}

Based on the theoretical basis that leadership style is an approach used to understand the success of leadership, in relation to where the center of attention is directed to the leader. Leadership style in this research consists of 4 leadership styles namely, Leadership Directive, Consultative Leadership, Participative Leadership, and Delegative Leadership.

If the leadership style is carried out well by influencing / directing subordinates in such a way that the subordinates can work together in a group and encourage them in a particular goal, then the performance of employees can increase.

Leadership Coefficient 0.352 with a significant value of 0.024 shows that the variable leadership has a positive effect on performance. In other words, if the leadership variable is increased by one unit then the performance will increase 0.352 , the conclusion means the coefficient of leadership is statistically significant.

The results of the research showed that the tcount for the leadership variable was 2,338 and the significant value of leadership was 0,024 . Thus $\mathrm{H} 1$ is accepted. This means that leadership partially significant effect on KPP Pratama Watampone Staff Performance. This means that with good and proper leadership will have an impact on improving employee performance.

Among these leadership styles, the transformative leadership style of 4.336 is the most dominant style among other leadership styles. The transformative leadership style is a leadership style that emphasizes the amount of support and a bit of direction. Leaders make decisions together with subordinates, exchange ideas / ideas and support their efforts in completing tasks.

The results of this study are in line with the results of research conducted Tafsir et.al (2015) "transformative leadership provides pengruh on employee performance. According to Rivai (2003: 15) with the level of maturity of moderate to high or high moderate employees with cirri members are able to carry out the task but not steady to be responsible then the right leadership is transformative leadership.

The results of this study are in accordance with the situational theory which states the success of a leader is determined by the characteristics of leadership with certain behaviors that are adjusted to the demands of the leadership situation and organizational situation faced by calculating the factor of time and space. Situational factors that influence the leadership style.

\section{Effect of Motivation on Performance}

Motivation is a motivator and a driver to meet the needs that make employees eager and enterprising work which is a form of implementation that seeks to improve and shape the knowledge, attitudes, and behavior of these employees voluntarily strive hard to work hard and cooperatively with other employees and able to increase productivity . 
Based on the indicators of Maslow's hierarchy of needs, the coefficient of motivation is 0.324 with a significant value of 0.023 indicating that the motivation variable has a positive and significant effect on work performance. In other words if the motivation variable is increased by one unit then the performance will increase by 0.269 , the conclusion means that the motivation coefficient is statistically significant.

The results obtained tcount value for motivation variable 2.357 and significant value of 0.023, thus $\mathrm{H} 1$ accepted. This means that the partial motivation has a significant effect on the Performance of KPP Pratama Bone Regency of South Sulawesi Province. This means that with a high / good work motivation will have an impact on improving employee performance.

These results are in accordance with the fact that occurred in the field KPP Pratama Watampone Office, management attention to the needs of employees in miningkatkan motivation is good enough. Meeting the physiological needs with satisfactory salary standards so that the daily needs of employees can be fulfilled, the need for security is good with the health insurance and pension salary, social relationships with fellow employees and leaders in susana kinship with frequent events held together in the form of events warning done by the office so as to strengthen relationships among employees and leaders, the existence of employee performance appraisals conducted by the leadership each year spur every employee to improve performance, and the management gives every employee the opportunity to follow the training conducted by the office and continue formal education to the level which is higher by granting permission to study to campus located in Makassar and in Java, is in accordance with the observation of the respondent's level of education at the Office of KPP Pratama Watampone is high with S1a education level of $40.00 \%$ and education with S2 as much as $32.00 \%$.

In addition $41-50$ years of age as much as $44.00 \%$, when associated with the stages in the life cycle at age 41-50 years is the peak period in one's career. This means that employees who work at the Watampone Primary KPP are classified as employees who are at the peak of their careers, and employees of this class have a good level of maturity in completing the tasks assigned.

As is clear from the title of this study, the theories discussed here are the motivational theories about the needs hierarchy of Abraham Maslow. In this thesis, Maslow's theory will be the starting point and foundation for the idea of the invention of motivation to improve the performance of employees in the organization. There is no denying that today there are various criticisms about the validity of this theory. But as a basic concept for the introduction of individual personal structures and the various factors that drive people to do something, this theory fits with the results of Stephen P. Robbins's research, in the book Organizational Behavior, writes that "despite all-out criticism, it seems (Maslow's theory) the best explanation about employee motivation. Other theories that emerged after Maslow's theory was more of a refinement and adaptation than the discovery of a completely new theory.

\section{Organizational Culture Against Performance}

Culture has a number of functions in the organization. First, it serves as a determinant of boundaries, meaning that culture creates a distinction or distinction between one organization and another. second, it contains the sense of identity of the members of the organization. Third, the culture of reconciling the commitment to something greater than the individual interests. Fourth, bidaya enhances the stability of social systems. Culture is a social glue that helps unite organizations by providing standards about what employees should say and do, and finally culture acts as a mechanism for sense-making and control that guides and shapes employee attitudes and behavior. (Robbins, 2007)

Coefficient of organizational culture $-0,044$ with Significant value equal to 0,778 indicate that organizational culture variable have negative effect to performance. The results obtained 
tcount value for organizational culture variable -2.284 and significance value of 0.778 . Thus $\mathrm{HO}$ accepted and $\mathrm{H} 1$ This means that the organizational culture is partially no effect on the Performance of KPP Primary Staff Watampone. This implies that the organizational culture applied in KPP Pratama Watampone provides negative impact on improving employee performance.

The results of this study prove that organizational culture has a negative influence on employee performance, meaning that the results of the implementation of the organizational culture that is carried out do not necessarily have an impact that is always positive or good for the organization. time.

The implementation of more organizational culture towards pressuring employees can cause an employee to achieve work performance, but not necessarily can have a positive influence in changing organizational culture to be carried out by subordinates to work sincerely towards achieving organizational goals.

Rivai (2003) in Waridin and Masrukhin (2006) states that the better the work culture the performance will be higher and vice versa. This means that any improvement in work culture towards a more conducive one will make a significant contribution to the improvement of employee performance, and vice versa.

\section{CONCLUSIONS AND RECOMMENDATIONS}

\section{A. Conclusion}

1. Hypothesis testing results on Simultaneous Test (F) Leadership, Motivation, and Organizational Culture have a positive and significant effect on employee performance at the Watampone Primary KPP Office

2. The results of testing the hypothesis in the Partial (T) Test of Leadership and Motivation have a significant positive effect on the performance and Organizational Culture does not affect the performance of employees at the Watampone Primary KPP Office

3. Leadership variable is the variable that has the most dominant influence on employee performance in KPP Primary Office Watampone

\section{B. Suggestions}

1. The Director General (Dirjen) of Taxes should improve Leadership, Motivation, and Organizational Culture to improve employee performance in the Watampone Primary Tax Service Office for example through education and leadership training, improving employee competencies and improving Organizational Culture.

2. For Researchers furthermore expected to study more deeply about this research, so this research become one of information that can be used for further research.

\section{REFFERENCES}

Achmad Sobirin, Achieved Excellence through Human Resources Integration and Strategic Planning, Special Edition Journal Business Focus On Human Resources, 2005

.Andi Kusuma, Privatization: Implications for Changing Employee Behavior and Organizational Culture, Special Edition of Business Strategy Journal On Human Resources, 2005.

Armanu Thoyib, Leadership Relations, Culture, Strategy and Performance; Approach Concepts, Management \& Entrepreneurship Journal Vol.7 No.1, March 2005. 
Arikunto, Suharsini, 2007. Research Management, Rineke Cipta, Jakarta

News, Finance Minister: Bad Image Tax Correction and Customs, Kompas Cybermedia, 27 April2006

Budi Cahyono and Suharto, The Effect of Organizational Culture, Leadership and Work Motivation on Human Resource Performance at JRBI Vol 1, January 1, 2005

Buhler, Patricia, 2004, Alpha Teach Yourself Management Skills, First Edition translated by Sugeng Haryanto, Sukono Mukidi and M. Rudi Atmako, Jakarta

Dubrin Andrew J., 2005. Leadership, Second Edition, Prenada Media, Jakarta.

Fred R. David 2005, Management Strategy, Edition 10 jakarta Salemba 4

Gunadi, 2004, Taxation Administration Reformation in the Framework of Contribution Towards Good Governance.Salemba 4

Hamid, 2002, New Organizational Culture Influence on Work Motivation and Achievement,

Hasibuan Melayu SP, 2001. Management: Basic. Understanding and Problems, Jakarta: Rineka Cipta

Luthans, Fred. 1998. Organizational Behavior. Eight Edition, Mc .rowth-Hill Book coSingapore.

Makmuri Muchlas, 2005, Organizational Behavior, Gadjah Mada University Press.

Mangkunegara, Anwar Prabu, 2004. Human Resource Management Company, Bandung: PT. Youth Rosdakarya

Organization and Administration Directorate General of Taxes, May 2005, Guarding Tax Reform Towards Independence State Finance, Jakarta, Indonesia.

Robbins, Stephen P, 2001. Organizational Behavior, Book I Interpreting: Diana Angelica, Jakarta: Salemba Four

Waridin and Masrukhin (2006), Relation of Organizational Culture to Employee Performance. Salemba 4 Jakarta.

Iman Ghozali, 2005. Business Research Methods. Alfabeta Bandung

Siagian, SP, 1994, Human Resource Management, Earth Script bandung

Sugiman, 2006, Effect of Leadership, Work Motivation and Work Discipline on Employee Work Achievement. YKPN Jogja

Tafsir Muhammad et. al (2015). The Role of Transformational Leadership On Creativity Climate Development In Workplace. Humanistic Management Network Journal.

Taxation Administration Modernization Work Team for the Medium Term Directorate General of Taxation, 2005, Operational Work Plan for Tax Administration Administration Modernization Team Period 2005-2009, Jakarta, Indonesia.

Tika H. Moh. Pabundu, 2006. Corporate Culture and Company Performance Improvement, First Mold, PT. Bhumi Aksara, Jakarta. 